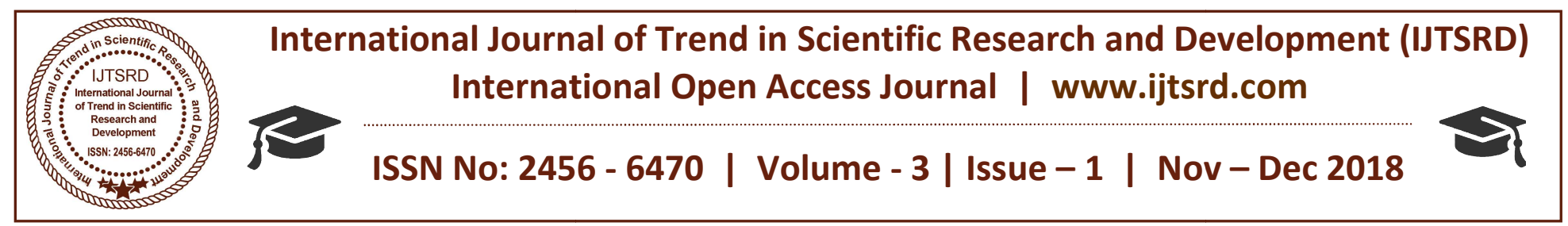

\title{
A Study on Credit Appraisal System in India with Special Reference to South Indian Banks
}

\author{
Mrs. P. Dhanya ${ }^{1}$, Dr. K. Vanaja ${ }^{2}$ \\ ${ }^{1}$ Assistant Professor, ${ }^{2}$ Professor and Head \\ Department of B.Com (PA), Dr. N. G. P. Arts and Science College (Autonomous) \\ Coimbatore, Tamil Nadu, India
}

\begin{abstract}
This study helps in understanding the credit appraisal system of Banks in India and to understand how to reduce various parameters, which are broadly categorized into financial risk, business risk, industrial risk and management risk associated in providing any loans or advances or project finance.
\end{abstract}

The research design was analytical in nature. Only secondary data was collected to this project. Using this collected data; analysis work was done in the area of Micro and Small enterprises.

After the analysis of this study, it was found that the following are the factors that will be considered by the Banks in credit appraisal process. They are financial performance, business performance, industry outlook, quality of management and conduct of account. In the factor of financial performance, the operating and financial viability of the proposal was found.

This study helps to know the credit appraisal process and understand the operating and financial viability of the proposal.

KEY WORDS: Credit Appraisal, Financial Risk, Business Risk, Industrial Risk, Management Risk, Financial Viability

\section{INTRODUCTION}

Credit appraisal means an investigation/assessment done by the Banks prior before providing any loans \& advances/project finance \& also checks the commercial, financial \& technical viability of the project proposed its funding pattern \& further checks the primary $\&$ collateral security cover available for recovery of such funds.

\section{MAIN THEME OF THE PROJECT}

\subsection{STATEMENT OF THE PROBLEM}

The study is to examine credit appraisal system based on the three enterprises and the problems identified by the researcher related to Micro and Small enterprises and the factors responsible for their sickness are infrastructure, limited financial resources, obsolesce technology, financial problems, low quality image. This study is to compare the three enterprises with financial viability and to find out the conclusion.

\subsection{OBJECTIVES}

To study the Credit appraisal system in Micro and Small enterprises sector the following objectives are framed

To Study about the Credit appraisal process.

To Study about the factors of operating and financial viability.

To Study about how they are giving rating's to the sectors.

To provide necessary findings based on the given data. 


\subsection{SCOPE AND LIMITATION}

\subsubsection{SCOPE}

The study will help in understanding the credit appraisal system at Banks and to understand how to reduce various risk parameters associated in providing any loans or advances or project finance.

\subsubsection{LIMITATION}

1. The credit appraisal is one of the crucial areas for any Banks, some of the technicalities are not revealed. This system includes various types of detail studies for different areas of analysis, but due to time constraint, the analysis was in the area of Micro and Small enterprises only.

\subsection{RESEARCH METHODOLOGY}

\subsubsection{RESEARCH DESIGN}

Research type: The study is based on analytical research. Analytical research describes to use facts or information already available and analyze these to make a critical evaluation of the material.

\subsubsection{TOOLS}

The tools used in Credit Appraisal System are

$>$ Pre-sanction process- The loan will be sanctioned only before analyzing various details of the enterprises is pre-sanction process.

$>$ Post-sanction process-After analyzing various details of the enterprises in pre-sanction process the loan will be sanctioned.

\subsection{REVIEW OF LITERATURE}

Allen N. Berger, Gregory F. Udell (2012) illustrates the inner workings of relationship lending, the implications for Banks organizational structure, and the effects of shocks to the economic environment on the availability of relationship credit to small businesses.

Michael B Gordy (2014) illustrates that within the past two years, important advances have been made in modelling credit risk at the portfolio level. Researchers offer a comparative anatomy of two especially influential benchmarks for credit risk models, the Risk Metrics Group's Credit Metrics and Credit Suisse Financial Product's Credit Risk+.

Michael B Gordy (July 2014) Credit Risk+ is an influential and widely implemented model of portfolio credit risk. As a close variant of models long used for insurance risk, it retains the analytical tractability for which the insurance models were designed.

Jan Pieter Krahnen, Martin Weber (2015) Banks internal ratings of corporate clients are intended to quantify the expected likelihood of future borrower defaults. It develops a comprehensive framework for evaluating the quality of standard rating systems. It suggest a number of principles that ought to be met by "good rating practice".

Seth B. Carpenter, William Whitesell, Egon Zakrajsek (2016) A researcher evaluates the potential cyclical effects of the "standardized approach" to risk evaluation in the new Accord, which involves the ratings of external agencies. Researchers find that the level of required capital against business loans would be noticeably lower under the new Accord compared with the current regime.

\section{ANALYSIS AND INTERPRETATION}

\subsection{INTRODUCTION TO CREDIT TOOLS}

The Banks has developed tools for better credit risk management. These focus on the areas of rating of corporate (pre-sanctioning) of loans and monitoring of loans (post-sanctioning). The focus of this manual is to familiarize the user with the credit rating tool.

\subsection{PARAMATERS USED IN CREDIT RATING OF SME}

The rating tool for Small and Micro Enterprise borrowers assigns the following weightages to each one of the four main categories as in the table 1.

\begin{tabular}{|l|l|}
\hline \multicolumn{1}{|c|}{ Parameter } & \multicolumn{2}{c|}{ Weightage (\%) } \\
\hline Financial performance & 40 \\
\hline Operating performance & 22.5 \\
\hline Quality of management & 22.5 \\
\hline Industry outlook & 15 \\
\hline
\end{tabular}

Various parameters under each of the above stated parameters 
International Journal of Trend in Scientific Research and Development (IJTSRD) ISSN: 2456-6470

\section{$\begin{array}{lllllll}\text { 3.3 PARAMETERS } & \text { OF } & \text { FINANCIAL } & 3.4 & \text { PARAMETERS } & \text { OF } & \text { OPERATING }\end{array}$ PERFORAMCE AND ITS WEIGHTAGE \\ PERFORMANCE AND ITS WEIGHTAGE}

\begin{tabular}{|l|l|l|}
\hline S.No & Sub Parameters & $\begin{array}{l}\text { Weightage } \\
(\%)\end{array}$ \\
\hline F1 & Net sales growth rate (\%) & 10 \\
\hline F2 & PBDIT growth rate (\%) & 7 \\
\hline F3 & PBDIT/Sales (\%) & 10 \\
\hline F6 & TOL/TNW & 10 \\
\hline F7 & Current ratio & 10 \\
\hline F8 & Operating cash flow & 8 \\
\hline F9 & DSCR & 8 \\
\hline F12* & Foreign exchange risk & 10 \\
\hline F13 & $\begin{array}{l}\text { Expected values of D/E, if 50\% } \\
\text { of } \\
\text { devolves(Corrected for margin) }\end{array}$ & 5 \\
\hline F24 & Reliability of Debtors & 12 \\
\hline F27* & State of export country economy & 5 \\
\hline F28* & Fund repatriation risk & 5 \\
\hline & TOTAL & $\mathbf{1 0 0}$ \\
\hline
\end{tabular}

\begin{tabular}{|l|l|l|}
\hline S.No & \multicolumn{1}{|c|}{ Sub Parameters } & \multicolumn{1}{|c|}{$\begin{array}{c}\text { Weightage } \\
(\%)\end{array}$} \\
\hline B7 & Credit period allowed & 10 \\
\hline B8 & Credit period availed & 10 \\
\hline B9 & Working capital cycle & 20 \\
\hline B10 & Tax incentives & 10 \\
\hline B13 & Production related risks & 10 \\
\hline B14 & Product related risks & 10 \\
\hline B15 & Price related risks & 10 \\
\hline B20 & Client risk & 10 \\
\hline B21 & Fixed asset turnover & 10 \\
\hline & TOTAL & $\mathbf{1 0 0}$ \\
\hline
\end{tabular}

*Applicable for export units

CASE - 1

Name of the Company

M/s Sivakumar Spinner

Present proposal

\begin{tabular}{|l|l|l|l|}
\hline \multicolumn{1}{|c|}{ Nature } & \multicolumn{1}{c|}{ Limit } & \multicolumn{1}{c|}{ Proposed } & \multicolumn{1}{c|}{ Purpose } \\
\hline Cash Credit Open Loan(CCOL) & 100 lakhs & 100 lakhs & Working capital \\
\hline Term loan & 90 lakhs & 90 lakhs & $\begin{array}{l}\text { To } \\
\text { machinery }\end{array}$ \\
\hline Fully Security Loan (FSL) & 120 lakhs & 120 lakhs & $\begin{array}{l}\text { To import machinery } \\
\text { valued Euro } 1,80,000\end{array}$ \\
\hline
\end{tabular}

\section{Security details}

\section{a) Primary}

\begin{tabular}{|l|l|l|}
\hline \multicolumn{1}{|c|}{ Particulars of asset } & \multicolumn{1}{|c|}{ Value / Margin } & \multicolumn{1}{|c|}{ Mode of change } \\
\hline Cash Credit Open Loan & $25 \%$ for stock and $50 \%$ for debtors & Hypothecation \\
\hline Fully Security Loan & $25 \%$ & Hypothecation \\
\hline
\end{tabular}


International Journal of Trend in Scientific Research and Development (IJTSRD) ISSN: 2456-6470

b) Collateral

\begin{tabular}{|l|l|l|l|l|}
\hline Nature & Owner & $\begin{array}{l}\text { Present year } \\
\text { valuation } \\
\mathbf{1 3 . 1 . 1 7}\end{array}$ & $\begin{array}{l}\text { Previous year } \\
\text { daluation dated } \\
\mathbf{2 3 . 3 . 1 6}\end{array}$ & $\begin{array}{l}\text { Expert } \\
\mathbf{1 8 . 1 . 1 7}\end{array}$ \\
\hline Unit property & Sivakumar spinners & 255.04 & 118.61 & 302.00 \\
\hline The mill & $\begin{array}{l}\text { Sivaswamy, andion } \\
\text { Rajkumar and } \\
\text { Sukumar }\end{array}$ & 219.78 & 75.49 & 329.18 \\
\hline
\end{tabular}

Purpose of loan $\quad$ : $\quad$ To purchase machinery

Validity of limits $\quad: \quad 12$ months

Term loan (OD) : : 1 year

Ratings by Banks : : AA with $76 \%$ (High safety)

\section{Unit Visit}

The unit was visited and the overall operations of the unit were found to be satisfactory.

CASE - 2

Name of the Company

M/s Rajsanthi Spinners

\section{Present proposal}

\begin{tabular}{|c|c|c|c|}
\hline Nature & Limit & Proposed & Purpose \\
\hline Cash Credit Open Loan(CCOL) & 150.00 lakhs & $\begin{array}{l}200 \text { (of which } 50.00 \text { lakhs } \\
\text { seasonalt }\end{array}$ & Working capital \\
\hline Fully Security Loan (FSL) & 22.00 lakhs & 56.00 (reduced to 19.23 lakhs) & Continuance \\
\hline
\end{tabular}

\section{Security details}

a) Primary

\begin{tabular}{|l|l|l|}
\hline \multicolumn{1}{|c|}{ Particulars of asset } & \multicolumn{1}{|c|}{ Value / Margin } & \multicolumn{1}{c|}{ Mode of change } \\
\hline Stock and Book debts & $25 \%$ for stock and 50\% for debtors & Hypothecation \\
\hline Machines & WDV Rs.211.91 lakhs & Hypothecation \\
\hline
\end{tabular}

\section{b) Collateral}

\begin{tabular}{|c|c|c|c|c|}
\hline Nature & Owner & $\begin{array}{ll}\begin{array}{l}\text { Present } \\
\text { valuation }\end{array} & \begin{array}{r}\text { year } \\
\text { dated }\end{array} \\
20.12 .17 & \end{array}$ & 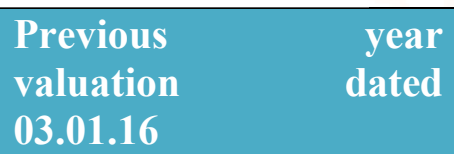 & $\begin{array}{l}\text { Expert } \\
\text { valuation } \\
25.12 .17\end{array}$ \\
\hline $\begin{array}{l}\text { Land with } \\
\text { Factoring }\end{array}$ & Mr.M.Thankaraj & 398.82 & 317.03 & 318.24 \\
\hline Vacant Land & Mr.M.Thankaraj & 144.70 & 99.00 & 99.80 \\
\hline
\end{tabular}


Purpose of loan : : To purchase machinery

Validity of limits : : 12 months

Term loan (OD) : $\quad 1$ year

Ratings by Banks : $\quad$ A with $68 \%$ (Adequate safety)

\section{Unit Visit}

The unit was visited and the overall operations of the unit were found to be satisfactory.

\section{FINDINGS}

Credit appraisal is done to check the technical and financial viability of the project proposed its funding pattern and checks the primary or collateral security cover available for the recovery of such funds. Credit is the core activity of the Banks and important source of their earnings which go to pay interest to depositors, salaries to employees and dividend to shareholders. Banks main function is to lend funds or provide finance but it appears that norms are taken as guidelines not as a decision making.

\section{CONCLUSION}

Banks loan policy contains various norms for sanction of different types of loans. These all norms do not apply to each and every case. Banks norms for providing loans are flexible and it may differ from case to case. Usually it is seen that credit appraisal is basically done on the basis of fundamental soundness. But, after different types of cases studies, the conclusion was such that the credit appraisal system is not only looking for financial wealth.

\section{REFERENCES}

1) Altman, E.I., Saunders, A., 2007. Credit risk measurement: Developments over the last 20 years. Journal of Banksing and Finance 21, 17211742.

2) Allen N. Berger, Gregory F. Udell., 2011. Small business credit availability and relationship lending: the importance of Banks organizational structure, Finance and Economics Discussion Series with number 2001-36. Board of Governors of the Federal Reserve System (U.S.)

3) A.J. Murphy., 2012. Appraisal and the small company. Personnel Review-Volume: 9 Issue: 4.

4) Carey, M., Treacy, W., 2012. Internal credit risk rating systems at large Bankss. Federal Reserve Bulletin 84 (11), 897-921.

5) Cantor, R. Packer, F., 2013. Differences of opinion and selection bias in the credit rating industry. Federal Reserve Banks of New York. Journal of Banksing \& Finance 1395-1417.

6) English, W.B., Nelson, W.R., 2015. Banks risk rating of business loans. Working paper, Board of Governors of the Federal Reserve System. Washington, DC.

7) Michael B Gordy., 2016. A comparative anatomy of credit risk models. Journal of Banksing and Finance 24 (1/2), 119-149, this issue. 